\title{
Immigrant Declarants and Loyal American Women: How Suffragists Helped Redefine the Rights of Citizens-ERRATUM
}

Rachel Michelle Gunter

https://doi.org/10.1017/S153778142000033X. Published online by Cambridge University Press, 4 August 2020.

\section{Collin College}

The affiliation heading was omitted from the original online version of this article ${ }^{1}$. It has been added to both online and in print.

\section{Note}

1 Rachel Michelle Gunter, "Immigrant Declarants and Loyal American Women: How Suffragists Helped Redefine the Rights of Citizens," Journal of the Gilded Age and Progressive Era 19 (October 2020): 591-606. https://doi.org/10.1017/S153778142000033X

Cite this article: Gunter RM (2020) Immigrant Declarants and Loyal American Women: How Suffragists Helped Redefine the Rights of Citizens-ERRATUM. The Journal of the Gilded Age and Progressive Era 19, 686-686. https://doi.org/10.1017/S1537781420000742 